\title{
No Suitcase
}

\author{
Lucia Nardo
}

Almost midnight BUT an airport never sleeps. The smell of aviation fuel hangs in the air, signs glow and garbled announcements battle against the whine of jet engines.

The sting of the winter wind forces me to pull my jacket tighter as I unload my father's suitcases from the car. Dad is flying out to a family wedding in Italy. He talks constantly, eyes shining like an excited child, not like a man in his late eighties.

After my mother's death, he moved next door to me and I am fiercely protective. I have insisted he travel Business Class for comfort and security, but the fare goes against everything he values about frugal living.

'You've scrimped your whole life. How many more times do you think you'll be able to go back?' The words had spilled from my insensitive mouth before I could stop them.

Dad lowered his eyes at this truth. We both knew it could be the last time he will see his six sisters and revisit Lastovo, the Adriatic island where he grew up. At his age, life is sadder and harder, without adding in the rigors of long-haul travel.

'Business Class allows you more room and extra luggage,' I argued. 'Think of your piano accordion.' A gifted self-taught musician, his accordion is the second great romance of his life after my late mother. 'You arrived in this country with one suitcase. You've worked so hard. You deserve to go back with more.'

He acquiesced, but only to two suitcases. His piano accordion occupies the larger case; summer clothes and toiletries, the smaller. 
At the check-in, an oversized vase of white orchids adorns the desk.

'This is why I must pay so much money,' Dad notes wryly.

I laugh and rub his arm, feeling soft flesh where once there had been taut muscle.

His gaze tracks away over my shoulder as it does when his memories take hold.

Perhaps he is remembering the young couple who arrived in Melbourne on a scorching December day in 1951 under the auspices of the International Refugee Organisation. Numb after forty days in rough seas and living the whole trip in separate quarters, they had worked their passage. Displaced from their homeland, no one welcomed Mum and Dad when they disembarked at the austere Station Pier in Port Melbourne. The heat that greeted them was unlike the crisp heat they knew. Searing wind and blistering sunlight stung their eyes until they could not see any shape for their lives beyond the bleak landscape, devoid of familiar architecture and culture.

Although my parents were literate and fluent in two languages, they knew no English. It would take a few years, factory and labouring jobs, a dictionary and a set of encyclopaedias to teach themselves this third one. Dad would go on to establish a local business and become the neighbourhood go-to contact for other refugees and migrants without English, helping people with documents, accompanying them to appointments and negotiating on their behalf. He would practice his music and organise community performances, as he still does today.

Back then, on that first inhospitable day, there was only an uncertain future, an anxiety-provoking environment, no money, no friends. Between them, packed with salvaged belongings and hope, was a lone suitcase.

How far from then the orchid-decorated desk must seem to Dad.

Regulations forbid me to accompany Dad through the departure doors so a staff member instructs him on how to get to the Business Class lounge. Dad nods, repeatedly.

When he steps away from the counter, his face is blank.

'You sure you know where to go, Dad?'

'Think so,' he says. The doubt in his voice makes my core flutter with panic.

A young man standing nearby introduces himself. 'My name's Ahmed. I'm on the same flight. I can take your father through and 
show him to the lounge.' He looks to be about twenty, dusky-skinned and ebony-eyed. He offers Dad a handshake then turns to me. 'I'll look after him.'

Dad thanks him and promises to telephone me on arrival. He trails away obediently after Ahmed without a backward glance. The departure doors close behind them, leaving me staring at my grainy reflection in the silver finish.

My panic increases. I had handed my father over to a stranger.

Driving home, the passenger seat is achingly vacant. I wipe away tears, thinking of Dad alone on his long journey and hoping that Ahmed will keep his word.

Twenty-six long hours pass. I am awake at four in the morning, fretting. Dad should have landed in Rome by now, but there is no call.

Three hours later, my agitation is unmanageable. I ring my aunt. When she answers, the background laughter tells me that Dad's there.

'Bella!' she gushes. 'Ecco papá!'

Dad takes the phone. I berate him for making me worry by not calling.

He chuckles at our role reversal. 'Don't worry! The flight was good. So much to eat!' He proceeds to list the menu items. At his age, everything is about food.

'How did you get on with Ahmed?'

'We had good talk. He goes to meet his father in Dubai. We went through the customs together. They gave him a full search. Take a long time. I worry for him so I wait near until he finish. Ahmed say happen every time he goes on the plane. He thinks because of his name and his skin.' Dad sighs. In it, I recognise the unspoken. He has never forgotten what it felt like to be the odd one out, the dago, the one viewed with suspicion.

I picture his snow-haired head bobbing as he mulls over this situation. 'He not in the Business Class, but when we land, we find each other to say goodbye. He was kind young man.' He pauses. 'Was hard for him when he come to Australia, like was hard for me.'

Dad's concern for Ahmed travels down the phone line.

'Promise to call me every few days,' I say brightly, trying to soften it.

'Si, si. Everyone was waiting when I arrive.' The pain in his voice segues to joy. 'I think Ahmed's father be happy to see his son, too. Is nice when you have someone to welcome you.' 
I imagine the commonality of those scenes. Ahmed embracing his father in Dubai, Dad's six sisters, showering him with hugs and kisses, excited chatter mingling with the noise of Fiumicino Airport.

It was hard to know what others read into Ahmed's features but, what Ahmed had seen in my father, was an old man in need of assistance and he had offered it unbidden. I send a silent thank you to the young stranger, grateful for the moments of connection and kindness that he and Dad shared across generations and culture.

'You've come a long way in your travels since you arrived in Australia with that one suitcase, Dad.'

He breathes into a lengthy silence then says quietly, 'I was lucky. Some people come with none.' 